\title{
A HISTORICAL PORTRAIT?
}

For the present purpose it is more convenient to dispense with the division between inner and outer triangles, and instead to take Rembrandt's seven sitters one by one, left to right in the front row, then right to left along the back, referring always to the original design of the picture as reconstructed in PI. 1.

\section{ADRIAEN SLABBERAEN}

Adriaen Slabberaen is the surgeon on the left of the picture (PI. 1), who is seated directly opposite the praelector on the other side of the table. He resembles the surgeon seated in the comparable position in de Keyser's picture (Pl. 5); they are not the same man, but like that surgeon, Slabberaen is one of the sitters who are usually thought to be turning unhistorically towards the viewer, or in other words not paying attention to the lecturer. ${ }^{7}$ A different interpretation is proposed here: his eyes are directed not at the viewer, but at the large open book which leans against a pile of smaller, closed books in the lower right corner of the canvas.

This interpretation is no more subject to proof than the traditional one, but a possible objection to it can be refuted. Almost all writers who have referred to the mountain of books locate it (to use the recurring phrase) "at the feet of the corpse", meaning, presumably, on or beyond the end of the dissection-table. ${ }^{8}$ If the books were so placed, Slabberaen would certainly not have to turn so far to his right in order to look at them. However, the gap between the under edge of the dissection-table and the bottom edge of the recto page implies that, in three dimensions, the books are supposed to be standing not at the feet of the corpse but on a free-standing structure between the table and the picture-plane. ${ }^{9}$ Immediately above the open volume, on the right edge of the canvas, one sees a brown vertical object, in natural light now dim, which looks like the left vertical back-strut of a chair on the seat of which the books are piled. ${ }^{10}$ These facts, together with the large page-height of the open volume approx. $46 \mathrm{cms}$. on the canvas - suggest that the book is to be understood as almost leaning out through the picture-plane. Hence Slabberaen, in looking at the book, looks at the picture-plane, and therefore in the direction of the viewer.

However, the object of his gaze is the book, not the viewer, and the book is not a symbol but a historical part of normal anatomical equipment. The engraving re-

\footnotetext{
${ }^{7}$ e.g. Mauritshuis p. 98.

'In 1887, Triaire (Heckscher [474] p. 14) located the book "au pied du cadavre", but this may have been a metaphor. Riegl (Heckscher [398] text vol. p. 185) placed it literally "zu Füssen des Leichnams", and this phrase recurs in numerous later works such as H. van de Waal's essay (Heckscher [504] p. 104), and Mauritshuis p. 99.

"As observed by Heckscher p. 67, though contradicted by the inevitable phrase "at the feet of the corpse" in the previous sentence.

${ }^{10}$ This marginal object is often cut off photographs, but is clearly reproduced in (e.g.) Mauritshuis pl. VII. It seems to have puzzled J. de Frey, whose etching of Rembrandt's picture (Fig. 1) was published in 1798. De Frey interpreted it as the right back strut of a different structure (a chair or something else) which would fill the still unexplained space behind Nicolaes Tulp.
} 


\section{The paradox of Rembrandt's 'Anatomy of Dr. Tulp'}

produced in Pl. 8, which depicts an anatomy at Leiden, suggests an anatomy-book was used on such occasions as a prompt-book for the praelector, ${ }^{11}$ while the engraved illustrations in the book served also to clarify the dissections and to provide a check against abnormalities. ${ }^{12}$ In Rembrandt's painting it is placed where it is - further from the participants than they could reach to turn the pages - precisely in order to give a historical reason for Slabberaen's showing his face to the viewer. In the case of this sitter, Rembrandt does seem to have introduced a device to turn an attributive pose, like that of the corresponding surgeon in de Keyser's picture (PI. 5), into a historical one (Pl. 1).

\section{JACOB DE WITT}

The surgeon on the right of Slabberaen, Jacob de Witt, cranes over the cadaver's head in order to follow the course of the forearm muscles which the praelector is demonstrating. Here also the pose is historical.

\section{MATHYS CALKOEN}

The surgeon who crouches down between Jacob de Witt and Nicolaes Tulp is identified as Mathys Calkoen. On the direction of his gaze there is no agreement: some think he is looking at Tulp's face, others that he gazes thoughtfully into the unfocused distance, and others that he is looking generally at "what the praelector is doing". ${ }^{13}$ Much is explained, however, if we assume that his eyes are directed specifically at Dr. Tulp's left hand. ${ }^{14}$

Calkoen bends forward and supports the weight of his trunk with his own left hand. The only reason for adopting such a posture would be to look downwards, at the dissected limb. Now he is looking up, but he has not had time to unbend his spine from its downward inclination. This is not the only sign of haste. He has raised his head to a higher angle than suits the posture of his trunk, but his head merely follows his eyes which already aim higher still. Hence his eyes seem to have darted up with a sudden glance which is now fixed on Nicolaes Tulp's left hand. ${ }^{15}$

Any explanation of Calkoen's sudden change of attention depends on one's interpretation of Nicolaes Tulp's gesture. To catch Calkoen's eye so sharply Tulp must have done something sudden, unexpected, and noteworthy. Yet his gesture has been called "a common gesture", "a stereotyped teaching gesture", "the gesture of restrained speech", "an eloquent gesture with his left hand, the Quibus dein orditur, which may be interpreted as [meaning that] he started his oration by setting out

\footnotetext{
1 Appendix III no. 14a, p. 73 below.

${ }^{12}$ Cf. p. 12 below, on Tulp's use of Laurentius.

${ }^{13}$ The interpretations of, respectively: Hofstede de Groot (Heckscher [229] p. 388); Jantzen (Heckscher [255] p. 314) and also Cetto p. 308; and Mauritshuis p. 103.

${ }_{14}$ Absent, as far as I know, from the specialist literature, this interpretation was eventually found only in Max-Pol Fouchet's Lire Rembrandt, Paris, Les Editeurs français réunis, 1970, pp. 33-34, and in Frederic Hartt's $A r t$, vol. 2, London, Thames \& Hudson, 1977, p. 261.

is H. van de Waal (Heckscher [504]; English version, 'The Syndics and their legend' in his Steps towards Rembrandt, Amsterdam, North-Holland, 1974, pp. 247-292) challenged this kind of "frozen moment" interpretation with provocative arguments that are here discounted.
} 


\section{A historical portrait?}

several points". ${ }^{16}$ It seems unlikely that such a purely formal gesture could have had such a mesmeric effect on Mathys Calkoen. Hence the attraction of the rival interpretation which appears to have held the field long before the one just described: namely, the idea that Tulp's gesture was an illustration in the living limb of the function of the muscles and tendons being demonstrated in the dead one. ${ }^{17}$ This idea deserves closer examination than it has received.

Dr. Tulp's gesture illustrates two anatomical points. His fingers are sharply flexed at each proximal interphalangeal joint, while the whole hand, to judge from the shading of the cuff, is slightly dorsiflexed (or "extended") at the wrist. Since the sharp palmar flexion of the fingers tends to induce the dorsiflexion of the wrist automatically as a synergic action, ${ }^{18}$ the latter can probably be discounted as being merely incidental on the finger-flexion, which is therefore the object of the demonstration. There is an anomaly in the portrayal of the fingers: when they are so flexed at the proximal interphalangeal joint, they are normally also flexed at the terminal, but here only the proximal joint is flexed. Such things do occur abnormally in nature, ${ }^{19}$ but considering how many opportunities for distortion the painter has at his command, ${ }^{20}$ we should prima facie attribute any variations to Rembrandt rather than to his model. Rembrandt, therefore, by declining to shade the tips of Tulp's fingers, has divided the chiaroscuro cleanly between the shaded proximal phalanges, and the bright, middle and unguinal phalanges. The effect of this simplification is to emphasize the rigidity of the praelector's fingers. ${ }^{21}$ Hence, if Dr. Tulp's gesture illustrates his dissection, he should be dissecting those muscles and tendons in the forearm which flex the fingers:

$m$. flexor digitorum superficialis (or sublimis) and $m$. flexor digitorum profundus, and the tendons that issue from them to the fingers.

Unfortunately, the interpretation of the dissection has long been a subject of dispute, and the most recent contributors to the debate have not even considered this identification of the muscles. ${ }^{22}$ Nevertheless, there are many independent arguments in its favour. Since the tendons which are visible in the fingers of the corpse have always been interpreted as the tendons which should emanate from precisely these two flexor

\footnotetext{
${ }^{16}$ The interpretations of, respectively: Riegl (Heckscher [398] text vol. p. 182); R. H. Fuchs, Rembrandt en Amsterdam, Rotterdam, Lemniscaat, 1968, p. 25; Heckscher p. 40; Mauritshuis p. 100 (slightly emended) and n. 43. The Latin words are quoted from J. Bulwer, Chironomia or the arte of manuall rhetorique, London, 1664, f.p. 94: after Bulwer's first illustration, "A. Audientiam facit" follows "B. Quibus dein orditur" ("with which he then begins"). Engraved $\mathrm{i}$ is often undotted, whence the false reading quibusdem in Mauritshuis, loc. cit.

${ }^{17}$ Probably "W. Burger" (Heckscher [77]) had this idea in mind in 1858 when he wrote of Tulp's "geste explicatif" (p. 193), "geste de démonstration" (p. 204). Paul Triaire in 1887 (Heckscher [474] p. 33) also called it a "geste de démonstration", and several later writers took the same line, such as Hofstede de Groot (Heckscher [229] pp. 387-8, "eine erklärende Gebărde") and H. Gerson, Rembrandt: paintings, London, Phaidon, 1968, p. 50, although many others rejected it, including those cited in note 16 above.

${ }^{18} \mathrm{~F}$. Wood Jones, The principles of anatomy as seen in the hand, 2nd ed., London, Baillière, Tindall \& Cox, 1941, pp. 231-232.

${ }^{19}$ A. Vesalius, De humani corporis fabrica, Basle, 1543, p. 124.

${ }^{20}$ As shown, for example, by the different lengths of the cadaver's right and left limbs in Rembrandt's painting.

${ }^{21}$ Hence the "wooden" effect noted by Gerson, loc. cit., note 17 above.

22 See Appendix I, pp. 52-54 below.
} 


\section{The paradox of Rembrandt's 'Anatomy of Dr. Tulp'}

muscles, the simplest interpretation of the two muscles being demonstrated is to identify them as the muscles which issue those tendons. As argued in Appendix I below, this interpretation is sound anatomically, provided one accepts a certain view (also the simplest) of the orientation of the limb.

According to this interpretation, the muscle Dr. Tulp holds in his forceps is $m$. flexor digitorum superficialis, while $m$. flexor digitorum profundus is the long straight muscle running underneath it (P1. 9). By lifting the superficialis away from the profundus, he reveals the way in which the two muscles combine their strength to flex the fingers. Hence the action of Tulp's left hand does illustrate the function of the muscles which he has chosen to display in the corpse. Moreover, this interpretation explains Mathys Calkoen's eagerness, for the mere topographical anatomy of this process is a thrilling drama composed of the three classical constituents, complication, reversal, and resolution. The two muscles originate from the same place on the inside of the elbow joint, but they soon wander apart. Just before they reach the end of their course, their tendons re-converge, and the one runs clean through the other (Pls. 9, 13; Figs. 2, 3) so that the upper (superficialis) becomes the lower, and the lower (profundus) the upper: a double peripeteia. In the dénouement, the two tendons find separate resting-places on the phalanges (Pl. 13; Fig. 3). But topographical description, however remarkable, is only a prelude to functional demonstration; or, to speak in terms familiar to Tulp, situs, numerus, and figura lead into actio and usus. In order to demonstrate the function of these muscles and tendons, the lecturer, we imagine, solemnly raises his free hand, and of a sudden flexes the fingers rigid, so instantly catching the eye of Mathys Calkoen. The fascination on Calkoen's face is designed precisely to show that Dr. Tulp's gesture is something more than an "allocutio-gesture". ${ }^{23}$ We may therefore say that Calkoen also has a historical role in the picture.

\section{NICOLAES TULP}

We have already reconstructed part of Nicolaes Tulp's role in the painting from the actions of his right and left hands, but more important still are the thoughts that give his face its meditative expression, and the words that fall from his open lips. These remain to be recovered. Fortunately they are still not quite beyond recall, but they can only be brought back to us through a study of the influences which shaped Nicolaes Tulp as an anatomist and as an Amsterdamer.

Two anatomists have already been proposed as Tulp's immediate models: Casserius and Vesalius.

(i) Julius Casserius of Piacenza (1552?-1616) was professor of anatomy at Padua. At his death in 1616, he left a set of unpublished anatomical illustrations without any text. His successor at Padua was Adrianus Spigelius of Brussels, who, on his death in 1625 , left an unpublished anatomical text without any illustrations. The two works,

\footnotetext{
${ }^{23}$ As Heckscher called it (pp. 33, 117). A selection of allocutio-gestures is reproduced in E. Panofsky's Problems in Titian, mostly iconographic, London, Phaidon, 1969, pls. 83-88. Tulp's gesture is quite different.
} 


\section{A historical portrait?}

though not intended to complement each other, were published together in Venice in 1627 as one doubly posthumous edition. ${ }^{24}$ In that edition, the second figure of Casserius's plate XXII (our Fig. 2, p. 10) shows the flexor muscles of the hand, and the belly of $\mathbf{m}$. flexor digitorum superficialis is artificially pulled away from $\mathrm{m}$. flexor digitorum profundus, as in Rembrandt's painting. It has therefore been suggested that Nicolaes Tulp modelled his dissection on Casserius's. ${ }^{25}$ It has been further proposed that the Casserian plate was followed not only by Tulp in his dissection, but also by Rembrandt in his painting of the dissection, on the ground that both pictures are said to show the same anatomical anomalies. ${ }^{26} \mathrm{We}$ shall examine these proposals in detail later (pp. 13-16 below).

(ii) Andreas Vesalius (1514-1564) is believed to have determined Tulp's choice of pose through the woodcut portrait of himself, dated 1542, which Vesalius prefixed to his Fabrica and other books (PI. 10). In the woodcut, Vesalius is shown demonstrating the flexor-muscles and -tendons of the fingers, as Tulp is in Rembrandt's painting: the muscle-belly which Vesalius offers in his right hand to the viewer is the same, $m$. flexor digitorum superficialis, as that which Nicolaes Tulp, with his right hand, holds up for the Amsterdam surgeons to see. Both are demonstrating the divergence and eventual convergence of the finger-flexors. The resemblance between the two pictures has been interpreted as a comparison on Tulp's part between Vesalius and himself, showing Tulp to be "the 'Vesalius redivivus' of the seventeenth century". ${ }^{27}$ Again, this suggestion will be further examined below (pp. 16-20).

However, these two anatomists were not the only sources of Dr. Tulp's anatomical knowledge, and before we test their influence on him, some of the others whom he knew should also be mentioned.

(iii) One anatomist who was especially esteemed by Tulp and his contemporaries was Andreas Laurentius or Dulaurens (1558-1609). Laurentius was appointed professor of anatomy at Montpellier in 1586. In 1598, he moved to Paris, and eventually became physician to Marie de Médicis and Henri IV. He wrote several books, on anatomy and medical subjects, which were republished many times up to $1778 .{ }^{28}$ The following sources, among others, indicate his reputation in the first half of the seventeenth century.

First, in 1637, Dr. Johannes Antonides van der Linden, then an examiner for the

\footnotetext{
24 Daniel Bucretius (editor), Adriani Spigelii . . de humani corporis fabrica libri decem, tabulis XCIIX ... exornati, Venice, 1627. The tabulae XCIIX are in the second part, which has its own title-page: Iulii Casserii . . tabulae anatomicae $L X X I I X$. . . Daniel Bucretius XX quae deerant suppleuit et omnium explicationes addidit. The numbering of the plates seems to include the title-page.

${ }^{25}$ C. E. Kellett, 'The anatomy lesson of Dr. Tulp', Burlington Magazine, 1959, 101: 150-152.

${ }^{26}$ A. Querido, 'De anatomie van de anatomische les', Oud Holland, 1967, 82: 128-136.

${ }^{27}$ Heckscher pp. 65-76, followed in Mauritshuis pp. 100-101, and by many other writers. Tulp possessed the Dutch translation of Vesalius's Epitome with Vesalian and Valverdian plates engraved by Pieter Huys, Antwerp, 1568. The copy in Utrecht University Library (shelfmark: $M$ fol 118 rariora) bears the inscription "Nicolai Tulpii" on the blank page facing the title-page, as was noted by F. de Feyfer in Janus, 1914, 19: 467. This edition lacks the Vesalius portrait, however.

${ }^{28}$ L'anatomie universelle ... par A. du Laurent, Paris, 1778. There may be still later editions.
} 
The paradox of Rembrandt's 'Anatomy of Dr. Tulp'

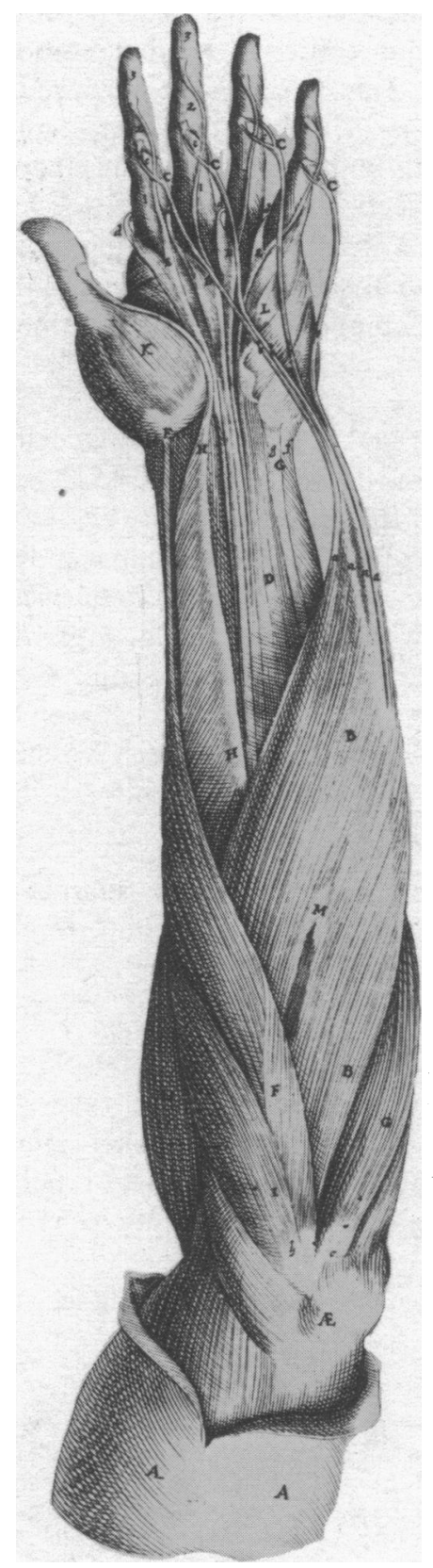

Figure 2. Francesco Valesio, flexor-muscles and -tendons of the forearm, engraving after a drawing by Odoardo Fialetti, c. 1600/1616, after dissections by Julius Casserius for his Tabulae anatomicae, Venice, 1627 , tab. XXII, fig. 2, this impression printed from the original copper in 1645 for the Amsterdam edition. The muscle flexor digitorum superficialis $(B M B)$ is divided at aaaa into four tendons which cre perforated at $C C C C$ and penetrated by the four lower tendons which issue from the flexor digitorum profundus $(D)$. 


\title{
A historical portrait?
}

Amsterdam college of physicians, and later to be the subject of one of Rembrandt's last etchings (PI. 12), published a guide to medical literature which was addressed to Pieter Tulp, Nicolaes Tulp's son and a recently qualified doctor of medicine at Leiden. ${ }^{29}$ This work, which contains eloquent tributes to the author's colleague Nicolaes Tulp, was re-edited in 1639 by Dr. Vopiscus Fortunatus Plemp, another Amsterdam physician who, since 1633-4, had occupied the chair of medicine at Louvain. ${ }^{30}$ Plemp had attended Nicolaes Tulp's public anatomy of 1632, as Rembrandt may have done, and also that of 1638. ${ }^{31}$ The choice of anatomy-books which van der Linden recommended to Pieter Tulp was unchanged in Plemp's edition. Considering the closeness and like-mindedness of these three physicians, one would provisionally expect the same choice of anatomy-books to agree with Nicolaes Tulp's own preferences.

The anatomy-books which van der Linden recommended, with Plemp's endorsement, were: the Historia anatomica of Laurentius, which was first published in 1589; the Theatrum anatomicum of the Basle anatomist Caspar Bauhin (Frankfurt a. M. 1605 and 1621); and the already mentioned De humani corporis fabrica of Casserius and Spigelius (Venice 1627). Pride of place, in the judgment of van der Linden and Plemp, should be given to Laurentius, who was said to surpass the others by his methodical organization, clarity, completeness, and care in discussing "controversial, doubtful, and obscure subjects". "Therefore", Pieter Tulp was advised,

\begin{abstract}
you should start with him [Laurentius], and he should be read through with full attention at least three times: the first time for the bare account of the parts; the second time the same, but comparing it with his plates or - better still - with the very accurate plates of Casserius; and the third time, so that it might stick more firmly in your mind, repeat the second reading [of Laurentius] but link his appendices on problems with their chapters in the text. ${ }^{32}$
\end{abstract}

Bauhin and Casserius-Spigelius were to be studied outside the anatomy-theatre in order to improve the student's understanding of parts already seen in the cadaver. Bauhin was also to be consulted during the dissection of parts not dealt with in detail by either of the others.

29 J. A. van der Linden, De scriptis medicis, libri duo. Quibus praemittitur ad D. Petrum Tulpium manuductio ad medicinam, Amsterdam, 1637. Van der Linden is mentioned by Nicolaes Tulp (1652), IV, c. 45, p. 371. On van der Linden's career: J. Banga, Geschiedenis van de geneeskunde en van hare beoefenaren in Nederland, Schiedam, Interbook, 1975 (facsim. of 1868 ed.), pp. $401-406$.

30 J. A. van der Linden, Manuductio ad medicinam, 2nd ed. by V. F. Plemp, Louvain, 1639.

31 V. F. Plempius, Fundamenta medicinae, 3rd ed., Louvain, 1654, II, sectio 5, cap. viii, p. 141. V. F. Plemp dedicated a vernacular anatomy-book to Tulp (cited Mauritshuis p. 111), and Tulp called Plemp "a man with a deservedly great reputation": Tulp (1641), I, c. 28, p. 60. On V. F. Plemp's career see Banga, op. cit., note 29 above, pp. 278-286. He is not to be confused (as e.g. by Heckscher, p. 151) with his brother C. G. Plemp, who accused Nicolaes Tulp of avarice (E. H. M. Thijssen, Nicolaas Tulp als geneeskundige geschetst, Amsterdam, 1881, pp. 3-4).

32 van der Linden, op. cit., note 29 above, fol. ${ }^{*} 5^{r-v}$, "In Anatomica non unus adeundus: pauci tamen. Et qui? me auctore, Laurentius, Spigelius, Bauhinus . . . Atque in his Laurentius primus primas teneat. Methodus ei facilis, perspicua, et ad discendum apud quem aptior? Apud quem tam absoluta? Iam controversa, dubia, obscura, quis diligentius tractauit? Quis explicuit melius quam meus anatomicus? Laurentium intellego; et praepono (nec impono: quia ex animo ita sentio) omnibus qui eamdem Spartam ornarunt. Igitur auspicato sumatur ab hoc initium, et cum omni studio perlegatur minimum ter. Semel nuda partium historia; iterum illa, sed cum auctoris aut, quod malim, Casserii accuratissimis tabulis conferenda; quae, ut firmius haereat, denuo iteretur, et suis quaeque capitibus quaestionum commentaria subnectantur." Repr. in 2nd ed., op. cit., note 30 above, pp. 23-24. 


\section{The paradox of Rembrandt's 'Anatomy of Dr. Tulp'}

Second, there is a remark published by the anatomist Jean Riolan the younger in 1649. Riolan also coupled the names of Laurentius and Bauhin, not inaptly since their books share a certain likeness due to the fact that each had revised his successive editions in the light of the revisions of the other's. Riolan said,

Laurentius and Bauhin are judged by all to be the most outstanding and skilful in the art of anatomy, and their works are lauded as being the most perfect and most accomplished, and are preferred to the others. For in this century the purest and truest anatomical science is sought from these two, because they wrote last, instructed by their own observations and thoughts, and also helped by the teachings of their predecessors. So ... in anatomical controversies they are cited and adduced as if they were, in anatomy, the supreme justices and referees from whom no appeal to others is allowed. ${ }^{33}$

Third, William Harvey, Tulp's counterpart as praelector anatomiae to the London surgeons, frequently cited Laurentius in the notes for his praelection of $1616 . .^{34}$ Chapter I of Harvey's De motu cordis (1628) opens with a paragraph derived from Laurentius's 'Quaestio de motu cordis', one of the "appendices on problems" which were recommended to Pieter Tulp by van der Linden and Plemp. ${ }^{35}$

Among other evidence, one can state that Laurentius's Historia anatomica was regarded as a standard work in universities from Italy to Scotland.$^{36} \mathrm{~A}$ copy of it is depicted in a Dutch vanitas still-life. ${ }^{37}$ Parts of it were translated from Latin into Dutch in $1634 .{ }^{38}$ But most important for our purpose is the fact that Nicolaes Tulp himself stated in print that he had used the plates in Laurentius's book as a "most trustworthy" control for his own findings in the course of dissection. ${ }^{39}$ Laurentius's influence on Tulp is therefore likely to have been important.

(iv) In the case-book which Tulp first published in 1641 under the title Observationum

\footnotetext{
${ }^{33}$ Johannes Riolanus, Animadversiones in theatrum anatomicum Caspari Bauhini. printed in his Opuscula anatomica nova, London, 1649, p. 255, “... cum Laurentius et Bauhinus in arte anatomica praestantissimi et peritissimi judicentur ab omnibus, eorumque opera tanquam perfectissima suisque numeris absolutissima laudentur, caeterisque praeferantur: nam hoc saeculo ab his duobus, purissima et uerissima petitur scientia anatomica, quoniam postremi scripsere, suis propriis observationibus et cogitationibus instructi atque aliorum praecedentium documentis adjuti. Propterea . . . in rerum anatomicarum controversiis definiendis citantur et producuntur uelut judices et arbitri supremi rei anatomicae, a quibus ad alios prouocare non licet."

${ }^{34}$ The anatomical lectures of William Harvey ..., ed. and transl. by G. Whitteridge, Edinburgh, Livingstone, 1964.

${ }^{35} \mathrm{~W}$. Harvey, An anatomical disputation ..., transl. and comm. by G. Whitteridge, Oxford, Blackwell Scientific Publications, 1976, p. 31, quoting from A. Laurentius, Historia anatomica, Frankfurt a. M., 1600 , p. 352.

${ }^{36}$ An Italian medical professor in the 1630 s or ' 40 s told his students "Si quis uestrum plenissimam et elegantissimam desideret humanorum corporum dignitatis enarrationem consulat Laurentium libro primo anathomes capitulo secundo qui disertissime omnium anathomicam rem agit", and made many other references to Laurentius (lecture notes in the Wellcome Institute, western MS 488, disputatio II, fol. 17). Lectures on Laurentius were given at Edinburgh in 1661, as recorded by A. Cunningham, 'The kinds of anatomy', Med. Hist., 1975, 19: 1-19, p. 8 and p. 16 n. 52.

37 W. Artelt (Heckscher [18] p. 1638) with an attribution to Dou. W. Martin, Gerard Dou, Stuttgart, Deutsche Verlags-Anstalt, 1913 (Klassiker der Kunst) p. XXI as in the manner of Vermeulen or Collyer.

${ }^{38}$ In J. van der Gracht, Anatomie der wtterlicke deelen van het menschelick lichaem, the Hague, 1634.

${ }^{39}$ Tulp (1641), I, c. 27, p. 57: near the sacrum of a dissected cadaver he failed to find "pilosa illa filamenta quae depingit Andraeas Laurentius, scriptor alioqui minime infidus". This plate by Laurentius would seem to be that on p. 179 of his Frankfurt 1599 edition, which shows the "horse's tail" effect produced only when a detached spinal cord is soaked in water.
} 


\section{A historical portrait?}

medicarum libri, he showed that he had consulted not only the works of Laurentius and the Casserius-Spigelius book, but also the anatomical works of Caspar Bauhin, Volcher Coiter, Realdus Columbus, Fabricius ab Aquapendente, and others. ${ }^{40}$

(v) Jean Riolan the younger (1580-1657) is also a possible influence on Tulp, since he too is cited in Tulp's book. ${ }^{41}$ Furthermore, Tulp's most quoted phrase, "Anatome verus medicinae oculus", appears to be taken without acknowledgement from Riolan's Anthropographia of $1626 .^{42}$

(vi) Last, one cannot rule out the possible influence of Pieter Paaw (1564-1617). Paaw initiated the study of anatomy at Leiden, was professor of anatomy while Tulp was a student there, and presided at the delivery of Tulp's doctoral thesis in $1614 .{ }^{43}$

Our list of possible influences on Tulp now contains: Casserius and Spigelius, Vesalius, Laurentius, Bauhin, Coiter, Columbus, Fabricius ab Aquapendente, the younger Riolan, and Paaw. That this list is unexceptional is shown by the fact that substantially the same authorities were used by the London praelector of anatomy, William Harvey. ${ }^{44}$ But how, if at all, did these anatomists transfuse their influence through Nicolaes Tulp into Rembrandt's painting? We examine them one by one, returning to the beginning of the list with the book by Casserius and Spigelius.

(i) The possible link between Tulp and Casserius has already been briefly stated. ${ }^{45}$ It seems to have several defects. It is incompatible with the Vesalian explanation, while unlike the latter it does not explain why, if Tulp did copy one of Casserius's seventyseven plates, he chose the plate showing the antebrachial musculature (Casserius's plate XXII). But it is not obvious that Tulp did imitate the Casserian dissection. The distinction between the deep and the superficial finger-flexors had been discussed by virtually all writers on general anatomy, and Casserius's dissection is entirely traditional. His plate XXII, fig. ii (our Fig. 2) shows an early stage in a dissection which Vesalius (Pls. 10,11) and Vidius ${ }^{46}$ had already chosen to illustrate at the next, more revealing stage, in which the origin of the flexor superficialis is cut and the belly retracted towards the viewer. These illustrations had been republished in the works of

\footnotetext{
${ }^{40}$ Tulp (1641), I, c. 27, p. 56 (Bauhin); III, c. 5, p. 191 (Bauhin and Coiter); II, c. 28, pp. 144 (Spigelius) and 145 (Columbus); II, c. 29, pp. 145-6 (Fabricius ab Aquapendente).

${ }^{41}$ Tulp (1652) IV, c. 44, p. 369.

${ }^{42}$ Riolan, Anthropographia et osteologia, Paris, 1626, p. 26, "dicere soleo Anatomen esse Medicinae oculum, quo quid agendum, quid vitandum admonemur atque pervidemvs." Cf. Tulp (1641) fols. ${ }^{*} 2^{v}-3^{r}$, "Anatome, verus medicinae oculus. Cuius lumine, ut irradiantur intima corporis penetralia, sic producuntur eiusdem beneficio quasi in claram lucem abditissimae occultorum morborum caussae: vera mehercule fulcra ac genuina artis medicae stabilimenta." and Tulp (1652), IV, c. 43, p. 367, "post ipsius obitum, omnium oculis exposuit anatome, verus medicinae oculus.", in which "ipsius" is the wife of Rembrandt's former pupil Govaert Flinck. Cf. p. 21 below.

${ }^{43}$ Thijssen, op. cit., note 31 above, p. 2. Paaw is mentioned by Tulp (1641), II, c. 13, p. 120. On Tulp as a student of Paaw see Beverwijck, p. 78 below.

Whittéridge, op. cit., note 34 above, pp. xiv-xviii.

is p. 9 above.

${ }^{46}$ Vidus Vidius (Guido Guidi), De anatome corporis humani libri VII, Venice, 1611 (published as vol. 3 of his Ars medicinalis), p. 195.
} 


\section{The paradox of Rembrandt's 'Anatomy of Dr. Tulp'}

Valverde, ${ }^{47}$ Bauhin, ${ }^{48}$ and Laurentius. ${ }^{49}$ Casserius's next plate (his pl. XXIII fig. i) shows precisely this next stage, of which the stage illustrated by Tulp is the logical precursor. The observed resemblance between the demonstrations of Casserius and of Tulp may owe less to cause and effect than to common practice which both record.

The further idea that Rembrandt copied the Casserian engraving is also open to doubt. The first of the anomalies which are claimed to prove the relationship is that the flexor-muscles in each picture originate not in their normal place, the medial epicondyle, but at a point far lateral to it. ${ }^{30}$ This certainly appears to be true of Casserius's plate (Fig. 2) in which the medial epicondyle, an important bony landmark near the letter $Æ$, is made conspicuous by being stripped of the fascia which normally obscures it. To accommodate this lesson, the origin of the flexor-muscles is inaccurately removed to one side. Rembrandt, however, could not have made this dubious concession, for in his painting neither the medial epicondyle nor the origin of the muscles has even been uncovered. What in the painting was formally identified with the medial epicondyle has now been shown to be merely a strip of tendon from the upper arm..$^{31}$

The second anomaly which is said to be shared by Casserius and Rembrandt is their common failure to show the parasagittal (or, on the canvas, vertical) stratification of the flexor-tendons as they leave the belly of $m$. flexor digitorum superficialis: the tendons to the index and little fingers should dive out from underneath the tendons to the middle two fingers, but in both the painting (Pl. 9) and the engraving (Fig. 2, marked aaaa) they seem to be on a level. ${ }^{52}$ However, this detail is significant only in morphology, and in 1632, when anatomists were more interested in teleology, it was still too trivial to find a place in the anatomical literature. Moreover, Galen had unwittingly diverted all anatomists' attention from it by remarking, correctly, that the coronal (or, on the canvas, horizontal) angle between each tendon and the next was equal; on their parasagittal relationship he said nothing, and anatomists influenced by him - such as Vesalius, Bauhin, Spigelius - were also silent. ${ }^{33}$ The parasagittal stratification seems not to have been published at all until 1685 , when it was recorded by, of all people, the painter Gérard de Lairesse in one of his incomparable caricatures for Bidloo's anatomy-book (Fig. 3, marked with arrows). ${ }^{54}$ Hence this imprecision of Rembrandt's associates him not with Casserius specifically, but with all anatomists of the time.

${ }^{47} \mathrm{~J}$. Valverde de Hamusco, Historia de la composicion del cuerpo humano, Rome, 1556, lib. II, plates V, VI, and with the same plate-numbers in the 1568 edition owned by Tulp, see nete 27 above.

${ }^{48} \mathrm{C}$. Bauhin, Vivae imagines partium corporis humani, Frankfurt a. M., 1620, lib. IV, tab. ix.

49 A. Laurentius, Historia anatomica, Frankfurt a. M., 1599, p. 185.

${ }^{\text {so }}$ Querido, op. cit., note 26 above, p. 135.

${ }^{31}$ See p. 53 below.

52 First noticed by J. Meyer, in Cetto p. 309, accepted by A. Querido, and later endorsed by Doctors Carpentier Alting and Waterbolk, op. cit., note 206 below.

${ }^{33}$ Galen, De usu partium I, 18, ed. G. Helmreich, Amsterdam, A. M. Hakkert, 1968 (repr. of 1907-9 ed.), vol. 1, p. 46.

${ }^{94} \mathrm{G}$. Bidloo, Anatomia humani corporis, Amsterdam, 1685, tab. 67. Although this feature must have emerged in Bidloo's dissections, he did not think it worth mention in his text, presumably because he could see no significance in it. Gérard de Lairesse's contacts with, and opinions of, Rembrandt are summarized by Seymour Slive, Rembrandt and his critics, the Hague, M. Nijhoff, 1953, pp. 159-166. 


\section{A historical portrait?}

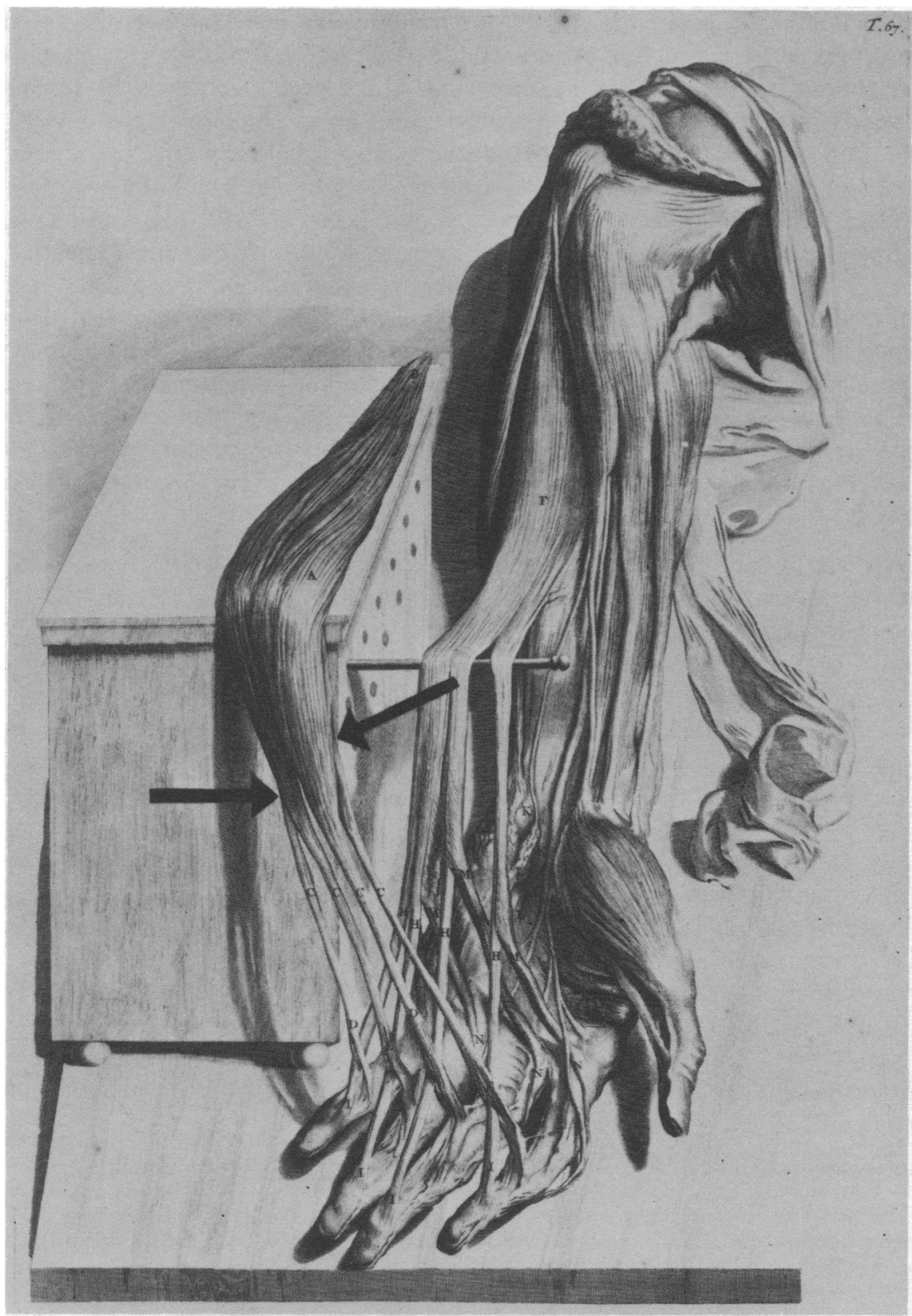

Figure 3. Pieter van Gunst (?), flexor-muscles and -tendons of the forearm, engraving, c. 1685, after a drawing by Gerard de Lairesse after dissections by Govaert Bidloo for his Anatomia humani corporis, Amsterdam, 1685, tab. 67. The muscle flexor digitorum superficialis $(A)$ is divided into four tendons (CCCC) which are perforated and penetrated by the four lower tendons (HHHH) which issue from the muscle flexor digitorum profundus $(F)$. Arrows added on photograph mark the stratification of inner over outer superficial flexor tendons: contrast Fig. 2 at mark aaaa, and see p. 14. 


\section{The paradox of Rembrandt's 'Anatomy of Dr. Tulp'}

There is other evidence which confirms Rembrandt's independence of Casserius. Among other differences, Rembrandt includes items which Casserius omits, such as a terminal branch of the ulnar nerve running along the little finger, the skin clinging to the fingertips, and, of course, the realistic colouring. The two depictions of the perforation of the superficial flexor-tendons are also completely different: Casserius (Fig. 2, marked cccc) illustrates it as a loose loop through which the deep tendon meanders freely, while Rembrandt, like Leonardo da Vinci (PI. 13), shows it more accurately as a taut sling which holds the deep tendon firmly on course towards the finger-tip (Pl. 9). There was no published woodcut or engraving from which Rembrandt's illustration could have been copied: he must have used a real limb, whether it was attached to a corpse or separated. But there is then no ground for introducing Casserius as his model. Indeed, if Tulp and Rembrandt had compared their finished picture with Casserius's equivalent engraving, they could only have agreed that their own work was far more accurate - whatever Doctors van der Linden and Plemp would tell the younger Tulp about the "very accurate plates of Casserius".ss

(ii) Vesalius. It can hardly be a coincidence that both Vesalius and Tulp chose to be portrayed demonstrating the flexor-muscles of the fingers (Pls. 10, 2). But what did Tulp mean by modelling his portrait on Vesalius's? Heckscher interpreted the likeness as implying that Tulp was to be thought a "Vesalius redivivus", 56 but for several reasons this seems improbable. There is no evidence that either that sobriquet or a similar one was claimed for Nicolaes Tulp by himself, by his contemporaries, or in fact by anyone before Heckscher (1958). Moreover, it is inappropriate for Tulp, since unlike Vesalius he was not an anatomist. Although, like many qualified physicians of that time, he had a working knowledge of anatomy, he was, as Heckscher remarks, "finally and principally a general practitioner". 57 His part-time appointment as lecturer in anatomy to the company of surgeons could not have led even his most extravagant admirers to rank Nicolaes Tulp with Vesalius. We must look for a different interpretation of Tulp's use of the Vesalian motif: such as, that the demonstration of the flexor-muscles of the fingers was supposed by Nicolaes Tulp, rightly or wrongly, to bear the same meaning for both Vesalius and himself.

The renowned aesthetic beauty of this dissection cannot have escaped the attention of either Vesalius or Tulp. Vesalius had certainly impressed it on his students at Bologna in 1540: according to one of them ${ }^{58}$ he demonstrated

how the [tendons issuing from the] muscles are situated on top of each other in double formation, always four on four [cf. Fig. 3]; and how the lower ones extend to the first joints, and the upper ones to the second and third, in each finger perforating the lower tendons. This was certainly a most beautiful sight. And he showed how a kind of special membrane covered those tendons, which he then separated and followed right up to the joints of the fingers. "On these", he said, "read Galen: On the use of parts books I and II, On the procedures of dissection book I, and On muscles".s9

ss Quoted on p. 11 above.

${ }^{36}$ See $n .27$ above.

37 Heckscher p. 75.

s8 Baldasar Heseler, whose notes were published by R. Eriksson, Andreas Vesalius' first public anatomy at Bologna 1540, Uppsala, Almqvist \& Wiksell, 1959. 


\section{A historical portrait?}

But the aesthetic aspect merely reflects a system of ideas about these tendons, which Vesalius's students could not have failed to encounter if they followed up their lecturer's reading-list. For Vesalius's recommendations remind us that our list of influential anatomists (p. 13 above) omitted the two most influential flgures in early seventeenth-century anatomy: Aristotle, and his follower in many matters, Galen. Bauhin's Theatrum anatomicum (1621) cites Aristotle and Galen more than any other authorities, and many of Laurentius's appendices on "controversial, doubtful, and obscure subjects", which were admired by van der Linden and Plemp, ${ }^{60}$ were intended to vindicate Galen against his "neoteric calumniators", Vesalius and Realdus Columbus. ${ }^{61}$ Could not the link between Vesalius and Tulp be their common acceptance of the Galenic view, derived from Aristotle, of the hand, the fingers, and the flexor-tendons?

According to a view which was discussed by Anaxagoras, recorded by Aristotle, and elaborated by Galen, the human hand was not a specialist instrument like the claws of the predator or the hooves of the herbivore, but an instrument at a higher level, an instrument for using other instruments, each for a different purpose. In this respect the human hand was the physical counterpart of the human psyche, which, by performing rational thought over an unrestricted range of subjects, was also an instrument for using further instruments. It was this instrumental application of both reason and the hand that had created human civilization and so raised man above the beasts: among other achievements, man alone tamed animals of superior bodily strength and speed, built places of worship, played musical instruments, and recorded thoughts in writing. The faculty by which the hand controlled its subservient instruments was prehension; the hand was therefore "the prehensile organ" ("opyovvov

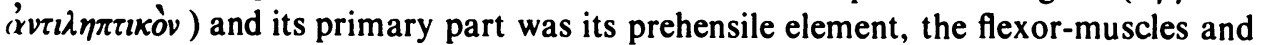
-tendons of the fingers. These muscles and tendons therefore had this first importance: that they, together with reason, the divine part of man, acted as the organ of civilization. ${ }^{62}$

But they were also important for a second and intrinsic property: their design was found to be uncannily sophisticated. The intersection of the flexor-tendons was particularly admired for its mechanical artistry. In the argument that all the parts of the body declared the wisdom and goodness of God in the creation of man, the construction of the human hand was one of the classic examples which could not be gainsaid. ${ }^{63}$

\footnotetext{
s9 Ibid., p. 96, "ostendit . . . quomodo duplici situ musculi super se situati sint quattuor semper super quattuor, et quomodo inferiores tenderent ad primos articulos: superiores autem ad secundos et tertios perforantes semper primos. Certe, hoc erat pulcherrimum uidere. Et quomodo isti tendines simul tecti erant quadam speciali pellicula, quos deinde separabat, et usque ad articulos digitorum perducebat. 'De his' inquit 'legatis Galeni 1. et 2. lib. de usu partium et 1. de administr. anath. Et de musculis membrorum'." In Heseler's nomenclature the "upper" tendon is that of the flexor profundus, the "lower" that of the flexor superficialis, both being named here from their relative positions after they have changed places in the perforation. This could be regarded as the obvious way of naming them from the point of view of a student standing near the feet of the cadaver.

${ }^{60}$ See $\mathrm{p} .11$ above.

61 A. Laurentius, Historia anatomica, Frankfurt a. M., 1599, lib. II, p. 66, and elsewhere.

${ }^{62}$ Appendix II nos. 1-2, pp. 57-58 below.

${ }^{63}$ See Appendix II below, passim.
} 


\section{The paradox of Rembrandt's 'A natomy of Dr. Tulp'}

Vesalius's reading list for his students, quoted above, would have exposed them to Galen's interminable variations on this subject. Having launched the theme in books I and II of On the use of parts, Galen brought it home in the last book (XVII) with the conclusion: "To a genuine investigator of Nature's works, the sight of the undissected arm alone is enough [to arouse admiration] . . . but even an enemy of Nature's, especially if he gazes on the art displayed in its inward parts as I explained it in books I and II, will lie awake at night if he seeks to find something to disparage among the things he has seen." 64 And of the tendons that flex the fingers: "their insertions in the bones and their relations with each other are amazing and indescribable. No words can anyway explain accurately things perceived through the senses alone. Yet one must try to describe them, for until their construction has been explained it is not possible to admire Nature's artistry [as it deserves]". ${ }^{65}$

The flourishing state of Galenic studies in the early sixteenth century made these ideas more familiar then than ever before. In 1536, the anatomist Niccolo Massa wrote: "the composition of the hand and of the instruments [muscles and tendons] which move it is a most beautiful sight which arouses the greatest praise of the good Lord." 66 On the combination of the superficial and deep flexor tendons of the fingers, Vesalius himself wrote with Galenic fervour that it was "a peculiar and rare occurrence ... due to the marvellous labour of the supreme Creator of the world."67 It is this miracle of anatomy that Vesalius demonstrates in the woodcut frontispiece to the Fabrica (Pl. 10).

It would be too easy to conclude that Vesalius's portrait was intended to show him revealing God's "marvellous labour" in the creation of the human hand. This interpretation could be supported on the ground that portrait-attributes were often selected to illustrate the sitter's piety, but it cannot be said to reflect an anatomical argument congenial to Vesalius. At this time (1542) Vesalius was fiercely obsessed with two ideas about anatomy. He supported the gathering of new facts as against the interpretation of established ones, and the dissection of human as against simian cadavers. These views were stated forcefully and frequently in Vesalius's preface and throughout his text. By comparison, the Galenic lessons of the philosophical and religious value of anatomy received little attention from Vesalius. Therefore, although the words on the hand which we have cited from Galen, Massa, and Vesalius suggest that the finger-flexor motif was able to serve as an illustration of the providence of the Creator, one may doubt whether Vesalius originally intended it to bear that meaning in his portrait, especially since it can be interpreted in other ways. Vesalius's dissection of the human hand and fingers does illustrate his two cardinal ideas about anatomy, and either its elegance or its difficulty alone could also have justified his choice of this dissection as his attribute.

When we look at the portrait through the eyes of Vesalius's contemporaries and followers, however, we see it in a different light, for few if any of them shared his lukewarm attitude to the use of anatomy in the Argument from Design. Their position

${ }^{64}$ Galen, De usu partium XVII, I, op. cit., note 53 above, vol. 2, pp. 442-443.

${ }^{65}$ Ibid., I, 17, vol. 1, p. 42.

${ }^{66}$ Appendix II no. 3, p. 58 below.

${ }^{67}$ Appendix II no. 4, p. 59 below. 


\section{A historical portrait?}

is epitomized in Abel Stimmer's engraved portrait of the Basle anatomist Felix Platter, dated 1578 (PI. 14). Platter holds a tome inscribed "VESAL.", while the legend beneath declares "COMPAGO MIRA CORPORIS NOSTRI DEI MIRACVLVM EST SOLERTIAE". ${ }^{6 s}$ For Platter and other admirers of Vesalius, to demonstrate the providence of the Creator was one of the main purposes of anatomy. Since Galen had proclaimed, with a certain prolixity, ${ }^{69}$ that the human hand provided irrefutable evidence for precisely this argument, it was the hand, and especially its primary part the finger-flexors, which became in the sixteenth century one of the preferred organs to demonstrate God's manifestation in the human body. ${ }^{70}$ In the words of the English praelector anatomiae John Banester, the hand was "so notably of the omnipotent Creator created, as that ... no member more declareth the unspeakable power of almighty God in the creatyng of man."1 Surely Banester and Platter would have interpreted the hand motif in Vesalius's portrait in this sense.

It is surely in this sense also that we should understand the allegorical design which the surgeon-anatomist Fabricius ab Aquapendente (1533-1619) used on the titlepages of his anatomical works published around $1600.12 \mathrm{~A}$ figure personifying surgery (Fig. 4, right) is identified as such from the three surgical instruments in her care, and the figure personifying anatomy (Fig. 4, left) displays as her attribute the flexor-

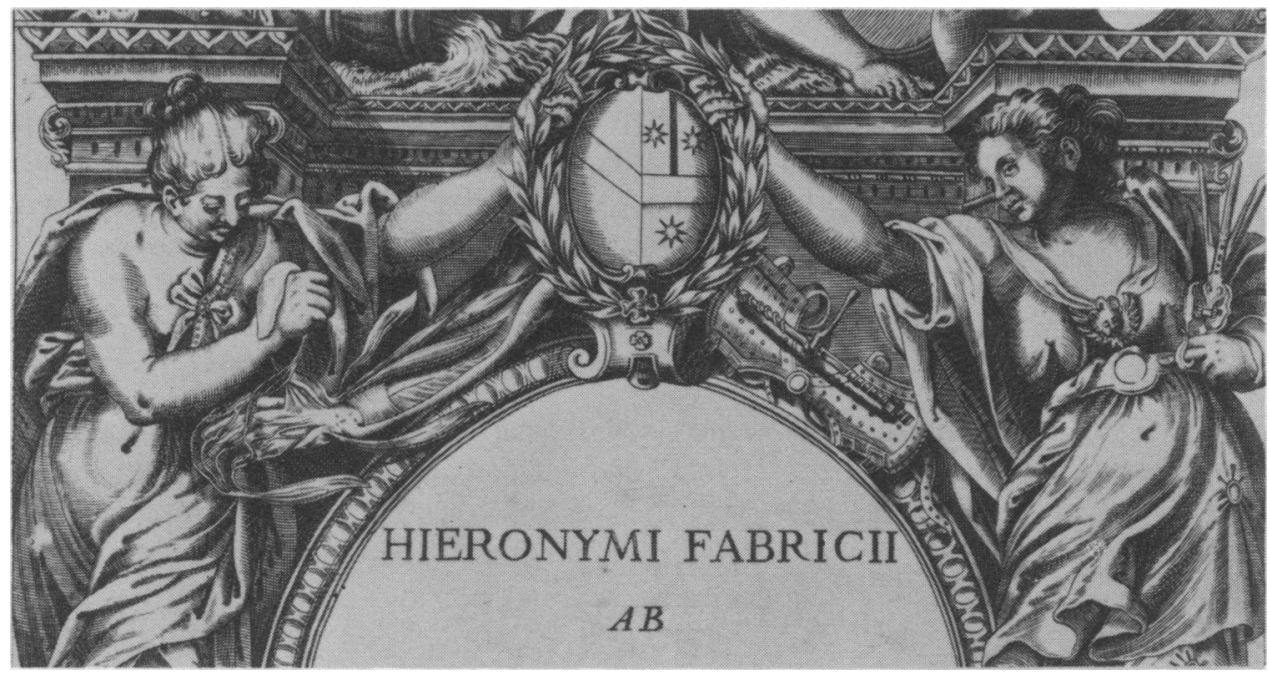

Figure 4. Giacomo Valesio, "Anatomia" and "Chirurgia", detail of engraving for Hieronymus Fabricius ab Aquapendente, De visione voce auditu, Venice 1600, title-page. The distinguishing attribute of Anatomia is her differentiation between $\mathrm{m}$. flexor digitorum superficialis and $\mathrm{m}$. flexor digitorum profundus.

\footnotetext{
"The marvellous construction of the human body is a miracle of the ingenuity of God".

69 As Jessenius, Universalis humani corporis contemplatio, Wittenberg, 1598, c. XXVIII, fol. C4', complained, "Quinque horum digitorum, sive processuum singulorum utilitatem I de usu part. Gal. prolixe exaggerat, ad quem lectorem remittimus."

${ }^{70}$ The anatomy of the eye was the favourite proof of this point, but it was on too small a scale to be demonstrated in a portrait, unlike the anatomy of the hand.

" J. Banester, cited in Appendix II no. 9, p. 61 below.
} 


\section{The paradox of Rembrandt's 'Anatomy of Dr. Tulp'}

muscles and -tendons of the fingers. In her right hand she holds $m$. flexor digitorum profundus, while $m$. flexor digitorum superficialis floats out towards the viewer. This is the same dissection as in the portraits of Vesalius (Pl. 10) and Tulp (Pls. 2, 9), and the fact that here Anatomia herself displays it refutes the idea that the demonstration of these tendons need imply homage to, or rivalry of, Vesalius. ${ }^{73}$ Instead, it implies that, if anatomy in general was, in the Galenic metaphor, "a hymn of praise to the gods", the anatomy of the finger-flexors served as its first, most eloquent, and representative part.

(iii) Laurentius. Of all the later sixteenth-century anatomists it was Laurentius who produced the amplest encomium of the hand, in his chapter de praestantia manus. ${ }^{74}$ Not only Aristotle and Galen but also Cicero and Quintilian were here ransacked to show that the hand was "the most noble and perfect organ of the body", and therefore one of the outstanding "doctors and teachers of divine wisdom". Laurentius did not fail to note the "marvellous artistry" with which Nature perforated the tendons of the flexor superficialis in order to provide the tendons of the flexor profundus with a passage to the distal phalanges, precisely the point demonstrated in the Vesalius and Tulp portraits. Anyone who saw Vesalius's portrait through the eyes of a follower of Laurentius must have interpreted it as a demonstration, through anatomy, of the power, wisdom, and goodness of God.

(iv) As a reader and admirer of Laurentius alone, Tulp would seem likely to have interpreted the Vesalian dissection in that sense. But the other anatomists whose works he also read interpreted the dissection of the hand in the same way, using phrases derived from Aristotle and Galen. The views of Columbus, Coiter, and Bauhin are given in Appendix II below. ${ }^{75}$ The fourth anatomist, Fabricius ab Aquapendente, did not complete his magnum opus in which he would have discussed the hand, but what he has left us, a pictorial allegory of Anatomy (Fig. 4), is probably to be interpreted in the same sense, as we have just suggested.

(v-vi) It is therefore no surprise to learn that the last two anatomists named above as having influenced Nicolaes Tulp - Riolan and Pieter Paaw - also eulogized the hand in the words of Aristotle, Galen, or both. ${ }^{76}$ Paaw's writing on the hand is typical of his whole approach to anatomy. He had felt an inner drive to study it which he had not felt for his other responsibility, botany: this, he thought, was

\footnotetext{
1 De visione voce auditu, Venice, 1600; also used with same date for De formato foetu, which, however. has a colophon dated 1604 .

${ }^{73}$ The interpretation of Heckscher (pp. 73-74), who saw examples of imitatio Vesalii in the portraits of (1) Casserius (Heckscher pl. XVII-21; Cetto no. 251); (2) Leo Bontius (on whom see F. Bernardi, Prospetto storico-critico dell' origine . . . del collegio medico-chirurgico . . . in Venezia, Venice, 1797, pp. 53, 58) by Leandro Bassano, now in Schwerin (Heckscher pl. XV-19; Cetto no. 245); and (3) Volcher Coiter attributed to Nicolas Neufchâtel in Nuremberg (Cetto no. 244). The pose of the Bontius portrait by Bassano is obviously indebted to Vesalius, but whether this portrait or either of the others has any conceptual relationship with Vesalius is open to doubt.

${ }^{74}$ Appendix II nos. 11 and 14, pp. 61, 62-63 below.

75 nos. 7,8 , and 12 , respectively.

${ }^{76}$ Appendix $I I$ nos. 13 and 16.
} 


\section{A historical portrait?}

either because I was touched by a kind of numinous quality in that divine temple [the human body]; or because man, for whose sake all other things were made, seemed to require more labour for his consideration; or because I judged that God himself intended greater, and more certain, evidence of His wisdom, power, and goodness, to appear in the formation of the human body than elsewhere."

From the point of view of the anatomists who shaped Tulp's anatomical style, the most important of whom were probably Laurentius and Paaw, Tulp's action in Rembrandt's painting must therefore have been interpreted as a deliberate demonstration that anatomy was a path to the knowledge of God. Is this opinion of Nicolaes Tulp's mentors a reliable guide to his own intention in choosing the dissection shown in Rembrandt's picture?

We have little direct evidence of Tulp's views on anatomy. He published no book on the subject, for he was, as we have stated, a general practitioner, whose chief interest was what has become known as pathology. We should not be misled by the fact that Tulp's name for pathology was anatome in his Latin writings and ontleding in Dutch: when Tulp wrote of anatome that it was the "very eye of medicine" 78 and that it "brought forth the truth as it were out of the shadow into the light", 79 he was thinking not of anatomical science, nor of public anatomies on the undiseased cadavers of executed criminals, ${ }^{80}$ but of a physician's dissections of his deceased patients, which (he hoped) would enable him to see, and not merely to guess, the causes of each symptom. ${ }^{81}$

But from Tulp's book on pathology we do have occasional glimpses of him at work in the anatomy-theatre. In one chapter he describes, as a prelude to a pathological case, the anatomical properties of the organ known as the ileo-caecal valve. We know that he lectured on this structure at his anatomy of 1632, and at several other anatomies in the $1630 \mathrm{~s} .^{82}$ The style of this anatomical passage is markedly different from the cool, "Hippocratic" tone of Tulp's writings on pathology. The parochial simile, the political analogy, the theological conclusion all suggest that here, for once, Tulp was writing not as Amsterdam's Hippocrates but as its Galen or Laurentius, that is, in the style, perhaps even the very words, which he used in his capacity as the city's praelector anatomiae. We must imagine Tulp holding up the ileo-caecal valve to the people of Amsterdam with the following explanation: ${ }^{83}$

\footnotetext{
${ }^{7}$ P. Paaw, Primitiae anatomicae, Leiden, 1615, fol. ${ }^{*} 2^{v}$, "neque diffiteor in hoc me genere laborasse impensius, sive quod religione quadam tangerer divini istius templi: sive quod homo, cuius causa facta sunt caetera omnia, plus mihi operae ad sui considerationem requirere videretur: sive quod iudicarem ipsum etiam Deum majora certioraque in corporis humani efformatione sapientiae suae, potentiae, $\&$ bonitatis voluisse quam in aliis apparere documenta."

${ }^{78}$ Tulp, loc. cit., note 42 above.

79 Tulp (1652), IV, c. 36, p. 353, with similar remarks at: II, c. 43, p. 174 (p. 168 of 1641 edn.); IV, c. 12, p. 317 ; IV, c. 29 , p. 341 ; IV, c. 43 , p. 367.

${ }^{80}$ Mauritshuis p. 94.

${ }^{81}$ As the passages cited in notes 42,79 , above show.

82 Plemp records the 1632 and 1638 demonstrations, loc. cit., note 31 above. Others are implied by Tulp's words, "aliquoties in theatro anatomico propalam ostensam": (1641), III, c. 21, p. 213.

${ }^{83}$ That Tulp held the "valve" up is inferred jointly from Plemp's objection to this practice, loc. cit., note 31 above, "Decet autem monstrare hanc valvulam intestinis naturaliter in corpore adhuc sitis; nam si exemta sint, posset auditoribus injici suspicio fraudis", and, if we can trust the evidence of PI. 15, from the use of this method by Adriaen van Valckenburg, the contemporary professor of anatomy at Leiden.
} 


\section{The paradox of Rembrandt's 'Anatomy of Dr. Tulp'}

If any chyme flows towards it from the ileum, [the valve] rises up and gives it free transit; and when the flow stops, it falls at once, expressly preventing any chyme from flowing back again from the colon or caecum into the ileum. It is exactly like our canal-locks in Holland: their sluices automatically open and close to an equal degree, and their double doors are so constructed that they open exactly as much in admitting the flow as they resist in pushing against it ....

$\mathrm{O}$ how lucky courtiers would be if they had such a guard [as the ileo-caecal valve] to keep from relapse the power which has flowed to them! Then they would certainly not fall so easily from the heights to the depths, nor would passing moments raise up and hurl down so frequently the achievement of slippery honour, and the confidence which depends on the might of another!

... If you are willing to examine [the valve] with care, you will surely penetrate the hidden nature of this mystery, and thus inevitably celebrate Divine Providence in these extraordinary monuments of His wisdom which God has so profusely established within us. ${ }^{84}$

On other occasions when Tulp approached anatomical or physiological topics, similar phrases came to his pen. The human body was the nobilis humanae fabricae compages, ${ }^{35}$ it possessed an incomprehensibilis consensus et admirabilis singularum partium inter se harmonia, ${ }^{86}$ this incomprehensible concord made manifest the impervestigabilis Dei omnipotentis providentia, ${ }^{87}$ or the impervestigabilis Dei omnipotentis sapientia, ${ }^{88}$ or the impervestigabilis Dei potentia;"9 and these manifestations of the inscrutable Deity showed man to be homo animal perfectissimum, ${ }^{90}$ or homo animal vere divinum. ${ }^{91}$ These passages seem to strengthen the hypothesis that Tulp's Laurentian treatment of the ileo-caecal valve was typical of his style in anatomy.

As further confirmation that Tulp's anatomies were designed to reveal the presence of God in man, there is Caspar Barlaeus's poem on the new anatomy-theatre at Amsterdam, which was inaugurated in 1639 when Tulp was still the praelector. ${ }^{92}$ In the second half of the poem Barlaeus imagines himself to be attending one of Tulp's anatomies, and his final verse is a two-line summary of the lesson which Tulp intended the anatomy to impart. ${ }^{93}$ The first line of the couplet will be discussed below, but the second line is relevant here: it is "Believe that God lies hidden in even the smallest part".94

\footnotetext{
${ }^{84}$ Tulp (1641), III, c. 21, pp. 214-9 "Si quid enim excretorum ab ileo effluit, attollit se, concedens illis liberum transitum; at cessante affluxu concidit ilico; impediens expresse, ne quid revertatur iterum a colo aut caeco ad ileum. Plane adinstar nostratium cataractarum, quarum repagula sponte non minus aperiuntur quam clauduntur. Quarumque bipatentes januae ita conformantur ut tantum pateant refluxui cedendo quantum renituntur fluxui obluctando . . . O fortunatos aulicos si tali, contra relapsum, custodia, firmaretur fluxa ipsorum potentia. Non deciderent certe tam facile a summis ad ima. Neque momentanea intervalla attollerent dejicerentque, tam frequenter idem, lubricae dignitatis fastigium, fiduciamque aliena vi innixam. . . . . siquidem lubet attente considerare, penetrabis procul dubio in absconditam huius arcani naturam. Et non poteris non celebrare divinam providentiam, et eximia illa sapientiae monumenta, quae in nobis profusissime constituit Deus."

${ }^{8 s}$ Tulp (1641), II, c. 6, p. 109.

${ }^{86}$ Ibid., I, c. 34, p. 68.

${ }^{87}$ Tulp (1652), IV, c. 54, p. 390.

88 Ibid. IV, c. 35, p. 349.

Tulp (1641), III, c. 29, p. 232.

${ }^{90}$ Ibid. I, c. 34, p. 68; Tulp (1652), IV, c. 9, p. 311.

${ }^{91}$ Ibid. III, c. 4, p. 188.

${ }_{92}$ The poem is more fully dealt with in Appendix IV, pp. 85-89 below.

${ }^{93}$ On this interpretation see pp. 88-89 below.

94 "Crede vel in minima parte latere Deum".
} 


\section{A historical portrait?}

If Dr. Nicolaes Tulp taught that even the ileo-caecal valve was one of the "monuments of God's wisdom", and that "even the smallest part [of the body]" revealed to the dissector the otherwise hidden presence of God, there can surely be no doubt that he intended the famous and exquisite intersection of the finger-flexors to carry the same meaning in Rembrandt's picture. Hence the words that we are to imagine coming from his open lips would be some such phrase as: "Behold the wisdom of almighty God which passeth all understanding". From his facial expression we are expected to understand that he is absorbed in the awesome mystery of God's self-revelation in human anatomy.

If we now ask again what historical significance there might be in Dr. Tulp's attitude in the picture, we gain an argumentum ex consequentiis which supports the interpretation that has just been proposed. For the three surgeons of the inner triangle, as we have observed, attend to Tulp's demonstration with such great interest that they look like novices learning the first steps in anatomy: hence the title "The anatomy lesson" which is colloquially often given to the picture.95 But these three sitters were experienced surgeons who must have been attending anatomies since the time of $\mathrm{Dr}$ Egbertsz.'s praelectorate. Moreover, the surgeon who seems most absorbed in the "lesson", Mathys Calkoen (lower left of Tulp), must have been familiar with the subject of Tulp's demonstration, since we are told that on at least one occasion he prepared with scrupulous care a dissection of the forearm muscles of a cadaver to enable Nicolaes Tulp to lecture on them at one of Tulp's public anatomies.96 The object of Calkoen's wonder therefore cannot be only the physical structure of the flexormuscles, which he already knew: it must also be some other aspect of them which a surgeon of some standing would not mind being portrayed as not having known before. The metaphysical implications of the flexor-muscles fill precisely this role. Thus our interpretation matches together, in a plausible historical unity, the impressive solemnity of Nicolaes Tulp's attitude, and the eager responses of the attentive surgeons.

\section{HARTMAN HARTMANSZ.}

The next sitter is the surgeon on the left of Dr. Tulp in the back row, Hartman Hartmansz. (PI. 1). As in the surgeon below him, Mathys Calkoen, his trunk and his head face in two different directions, Hartmansz.'s in a horizontal plane, Calkoen's in a vertical. Since Michaelangelo, this had been a standard device to suggest recent, rapid change of attention. Calkoen's pose implied that he had quickly jerked his head up from the dissection in order not to miss Tulp's dramatic demonstration. The object

\footnotetext{
9s Any title would be anachronistic, but this one is misleading as well. "Anatomy lessons" (lessen) were given every Tuesday and Friday: they did not require the presence of a corpse. "Anatomies", or "anatomical praelections" (Anatomie), did require a corpse, and were held only a few times a year. See e.g. B.W. Th. Nuyens, Het ontleedkundig onderwijs en de geschilderde anatomische lessen . . . 1550 tot 1798 , Amsterdam, van Kampen, [1927], p. 15. Rembrandt's picture alludes to the latter kind of occasion.

* See the quotation from J. J. van Meekeren, p. 55 below. In the Latin translation of van Meekeren's book, Observationes medico-chirurgicae, Amsterdam, 1682, by Abraham Blasius (Gerardi filius), the passage includes the words "in anatome aliqua publica ab Amplissimo D. Nicolao Tulpio in Theatro publico instituta ..." (p. 308).
} 


\section{The paradox of Rembrandt's 'Anatomy of Dr. Tulp'}

from which Hartmansz.'s attention has been suddenly diverted is an anatomy-book illustrated with Vesalian muscle-figures (Pls. 16, 11, 1).97 Rembrandt alludes to these much-copied écorchés with no more than a rough sketch: it did not suit his purpose to suggest a particular book, edition, or plate. The point under discussion, the intersection of the finger-flexors, was as clearly illustrated in the beautiful engravings after Vesalius in Valverde's or Laurentius's anatomy-book as in Vesalius's original woodcuts. ${ }^{98}$

The presence of the book in Hartman Hartmansz.'s hands is a characteristic feature of real anatomies. Some members of the audience at a public anatomy, especially if they could not see the corpse, followed the praelector's lecture in illustrated anatomybooks which they brought with them to the theatre (cf. PI. 17). By this means they could usually get as good an understanding of the anatomical argument as those who could see the corpse; often, indeed, a better understanding, when a complicated structure, obscure to the eye, had been illustrated diagrammatically. But when the topographical anatomy had been explained, and the praelector launched on his eloquent set-piece about its theological implications, there was nothing more to be learned from engravings, and all eyes would turn on the praelector to enjoy his rhetorical performance to the full.

This process provided Rembrandt with a pose for his portrait of Hartman Hartmansz. The image of Hartmansz., like that of Adriaen Slabberaen, was obliged to fill a space in such a position on the canvas that the dissection was not between him and the viewer. Hence, if he had been depicted looking at the dissection, his face would not have been visible and no portrait would have been possible. Therefore Rembrandt has provided for him, as for Slabberaen, a historical excuse for turning towards the picture plane without looking (attributively) at the viewer.

But what exactly is the portrait of Hartmansz. supposed to be looking at? It seems not impossible that he also may be looking at the gesture of Tulp's left hand. But it is perhaps more likely that we are meant to infer from his ruffled brow, divergent stare, and dropped jaw, that the startling implications of Dr. Tulp's demonstration are just dawning on the book-taught mind. While the novel thought sinks in, he forgets the book and gazes blindly into blank space. Through this response to the praelector's revelation, Hartmansz. also, the second of the three surgeons in the outer group, plays a historical, not an attributive, role in Rembrandt's pictorial drama.

\section{JACOB BLOCK}

Jacob Block is the surgeon to the left of Hartman Hartmansz. He forms the apex of

\footnotetext{
${ }^{97}$ Heckscher, pp. 67-70, identified this figure with the small woodcuts of the arm in Vesalius's De humani corporis fabrica, 2nd ed., Basle 1555, p. 259. But it looks to me much more like one of Vesalius's "dancing" écorchés (Pls. 16, 11), and I have reconstructed it thus in Pl. 1. This woodcut and the immediately following one in Vesalius both illustrate the particular structures being demonstrated by Tulp, unlike the figure adduced by Heckscher which illustrates muscle-fibre in general. A similar woodcut to that identified here was also included in the Miereveld anatomy-picture at Delft (Pl. 4), behind the skeleton in the top left corner, well illustrated by H. L Houtzager, Medicyns, vroedwyfs en chirurgyns, Amsterdam, Rodopi, 1979, p. 89.

${ }^{98}$ See notes 47, 49 above. Only the early Paris editions of Laurentius have engravings of artistic interest: the plates in the Frankfurt editions are hack-work copies.
} 


\section{A historical portrait?}

the inner triangle of surgeons. Jantzen first suggested that his eyes were directed towards the folio volume "at the feet of the corpse", and most modern scholars have agreed. ${ }^{99}$ However, if our relocation of the book closer to the picture-plane is accepted, this interpretation can no longer stand. ${ }^{100}$ I suggest that Block is looking instead, like Calkoen and for the same reason, at the flexed fingers of Nicolaes Tulp's raised left hand. Therefore Block's pose also is historical and not attributive.

Only one sitter now remains to be considered: Frans van Loenen, the hatted figure at the peak of the pyramid (PI. 1). Before we assess his role in the action, what has so far been proposed about first the genre, and second the subject, of Rembrandt's picture?

Leaving van Loenen out of account, we seem to have verified the view that Rembrandt has here composed a traditionally-commissioned group-portrait in the manner of a historical painting. As in a historical picture, there is a central action, in this case Tulp's demonstration of the metaphysical implications of the flexor-mechanism of the hand. The other characters seem to interpret the action and themselves to the viewer unwittingly, by reacting to it in various historically justifiable ways. Relative to the picture-plane, the sitters are all placed behind the objects of their attention, so that in looking at those objects they yield their portraits to the viewer without offending against historical rationality. Rembrandt has thus avoided the historically irrational attitudes found in the comparable paintings of his predecessors (Pls. 3, 4, 5, 6), and so, by the criterion of historical plausibility, he does appear to have surpassed his older colleagues, de Keyser and Eliasz.

The subject of the picture, as so far elucidated, is a pictorial adaptation of a type of scene which is well attested in the history of anatomy. At Leiden, when Pieter Paaw was about to perform one of his winter anatomies, crowds packed the stalls of the anatomy-theatre, and soon forgot the cold as Paaw kept them constantly astonished by revealing "the ingenious works of God in the human body" and by expounding "the proper office of every part". ${ }^{101}$ A similar scene was mentioned by Paaw's pupil Nicolaes Tulp, during a reference to the internal membranous lining of the larynx:

Nature, which foresees and controls every possibility, has constructed it with such sagacious industry that, whenever I have called attention to this skilfully made work of art in the anatomy theatre, the crowd standing around has always gazed on it with the greatest admiration. ${ }^{102}$

The anatomist Caspar Hofmann referred to the same kind of event in 1636 when he criticized the London praelector anatomiae William Harvey on the ground that

\footnotetext{
99 Jantzen (Heckscher [255]) p. 314.

100 See p. 5 above.

101 A composite account derived from poems by P. Scriverius and P. Bertius, cited in Appendix III nos. 14c, 14d, p. 73 below. The lines by Bertius translated here are: "Dum plenis monstras cuneis plenoque theatro/daedala in humano corpore facta Dei ...... sive ordine pandis/quodnam sit proprium partibus officium."

${ }^{102}$ Tulp (1652), IV c. 9, p. 311, "tam sagaci industria effinxit provida ac omnium opportunitatum moderatrix natura, ut affabre factum hoc artificium, nunquam nisi cum summa admiratione meminerim in theatro anatomico a circumstante corona conspectum."
} 


\section{The paradox of Rembrandt's 'Anatomy of Dr. Tulp'}

Harvey (like Tulp) held public anatomies for the benefit of surgeons, magistrates, and other impressionable laymen:

If only, Harvey, you would not hold anatomies in front of jacks-in-office, petty lordlings, money-lenders, barbers and such like ignorant rabble, who, standing around open-mouthed, blab that they are seeing miracles! 103

Rembrandt's picture can be checked not only against these texts but also against a second picture: the tiny engraving of 1641 which shows Adriaen van Valckenburg conducting an anatomy in the Leiden anatomy-theatre (Pl. 15). Here also the spectators near the corpse crane forward to catch the master's words and observe what he has to show them, in this case the ileum or its terminal valve.

Hence the devoted attentiveness and wonder which we see on the faces of Rembrandt's surgeons (except van Loenen) is an authentic detail derived from the expressions of spectators at actual anatomies. If the result reminds one of a Doubting St. Thomas, a Judas returning the silver, ${ }^{104}$ or a "Render unto Caesar", 105 it is because the baroque iconography of those subjects was essentially the same as the high moments of a public anatomy: several people marvel at something said or shown by one person. In Rembrandt's adaptation, the greatest change is obviously that of scale: acting, no doubt, on the same instructions as those given to Thomas de Keyser in 1619 (PI. 5), he has reduced a crowd-scene such as Pl. 8 to a group-portrait of half a dozen sitters (PI. 1). Other authentic details have been reconstructed as opportunity allowed. For example, the sitters are arranged in tiers recalling the precipitous flights of stalls in an anatomy-theatre: the effect, by which all eyes converge on the praelector from different heights, reproduces the wonderstruck atmosphere of the public anatomies performed by Paaw and Tulp, and derided by Hofmann.

${ }^{103}$ Caspar Hofmann, 'Digressio, in circulationem sanguinis, nuper in Anglia natam', in J. Riolan, Opuscula anatomica, varia et noua, Paris, 1652, pp. 357-364, p. 359 "Siquidem ô HARVEE, Anatomiam exerces, non apud Senatorculos, Patriciolos, Foeneratores, Barbitonsores, imperitumque vulgus, quod hianti ore adstans miracula videre gestit . .."; translation slightly modified from that of $\mathrm{G}$. Whitteridge, William Harvey and the circulation of the blood, London, Macdonald, 1971, p. 241.

${ }^{104}$ Keith Roberts in Burlington Magazine, 1971, 113: 353.

${ }^{105}$ E. K. J. Reznicek, 'Opmerkingen bij Rembrandt', Oud Holland, 1977, 91: 75-107, pp. 83-87. 